\title{
Dissolved Methane Distribution in the Reloncaví Fjord and Adjacent Marine System During Austral Winter (41 $\left.{ }^{\circ}-43^{\circ} \mathrm{S}\right)$
}

\author{
Laura Farías $^{1,2} \cdot$ Karen Sanzana $^{1} \cdot$ Sandra Sanhueza-Guevara $^{2}$ - Mariela A. Yevenes ${ }^{1,2}$
}

Received: 8 November 2016 /Revised: 15 March 2017 / Accepted: 17 March 2017 /Published online: 10 April 2017

(C) The Author(s) 2017. This article is published with open access at Springerlink.com

\begin{abstract}
Within the earth's atmosphere, methane $\left(\mathrm{CH}_{4}\right)$ is one of the most important absorbers of infrared energy. It is recognized that coastal areas contribute higher amounts of $\mathrm{CH}_{4}$ emission; however, there is a lack of accurate estimates for these areas. This is particularly evident within the extensive northern fjord region of Chilean Patagonia, which has one of the highest freshwater runoffs in the world. Oceanographic and biogeochemical variables were analyzed between the Reloncaví fjord $\left(41^{\circ} \mathrm{S}\right)$ and the Interior Sea of Chiloé (ISC) $\left(43^{\circ} \mathrm{S}\right)$, during the 2013 austral winter. Freshwater runoff into the fjord influences salinity distribution, which clearly delimits the surface ( $<5 \mathrm{~m}$ depth) and subsurface layers $(>5 \mathrm{~m}$ depth), and also separates the estuarine area from the marine area. In the estuary, the highest $\mathrm{CH}_{4}$ levels are generally observed in the cold and brackish nutrient-depleted surface waters (N- and P-depleted), ranging from 16.97 to $151.4 \mathrm{nM}$ (mean \pm SD 52.20 \pm 46.49 ), equivalent to $640-4537 \%$ saturation except for the case of $\mathrm{Si}(\mathrm{OH})_{4}$. Conversely, subsurface waters have lower $\mathrm{CH}_{4}$ levels, fluctuating from 14.3 to $29.6 \mathrm{nM}$ (mean \pm SD $22.75 \pm 4.36 \mathrm{nM}$ ) or $552-1087 \%$ saturation. A significant negative correlation was observed between salinity and $\mathrm{CH}_{4}$, and a positive correlation between $\mathrm{Si}(\mathrm{OH})_{4}$ and $\mathrm{CH}_{4}$, suggesting that some of the $\mathrm{CH}_{4}$ in estuarine water is due to continental runoff. Furthermore, the accumulation of seston and/or plankton at the pycnocline may
\end{abstract}

Communicated by Alberto Vieira Borges

Laura Farías

laura.farias@udec.cl

1 Departamento de Oceanografía, Facultad de Ciencias Naturales y Oceanográficas, Universidad of Concepción, Concepción, Chile

2 Centro de Ciencia del Clima y la Resiliencia (CR)2, Universidad de Chile, Santiago, Chile potentially generate the accumulation of $\mathrm{CH}_{4}$ via microbial processes, as observed in estuarine waters. By contrast, the marine area (the ISC), which is predominantly made up of modified subantarctic water, has a relatively homogenous $\mathrm{CH}_{4}$ distribution (mean $\pm \mathrm{SD} 9.84 \pm 6.20 \mathrm{nM}$ ). In comparison with other estuaries, the Reloncaví fjord is a moderate source of $\mathrm{CH}_{4}$ to the atmosphere, with effluxes ranging from 23.9 to $136 \mu \mathrm{mol} \mathrm{m}{ }^{-2}$ day $^{-1}$. This is almost double the levels observed in the ISC, which ranges from 22.2 to $46.6 \mu \mathrm{mol} \mathrm{m}{ }^{-2}$ day $^{-1}$. Considering that Chilean Patagonia has numerous other fjord systems that are geomorphologically alike, and in some cases have much greater freshwater discharge, this study highlights their potential to be a significant natural source of this greenhouse gas.

Keywords Methane $\cdot$ Fjords $\cdot$ North Chilean Patagonia

\section{Introduction}

Methane $\left(\mathrm{CH}_{4}\right)$ is an important atmospheric trace gas because it both directly (due to its stronger greenhouse effect) and indirectly (due to chemical reactivity) influences the Earth's climate (Wuebbles and Hayhoe 2002). Indeed, $\mathrm{CH}_{4}$ has important effect on both tropospheric and stratospheric chemistry, significantly affecting levels of the ozone, water vapor, the hydroxyl radical, and numerous other compounds (Wuebbles and Hayhoe 2002). $\mathrm{CH}_{4}$ concentration has doubled since the beginning of the industrial era, and the cause of this rise is believed to be due to anthropogenic sources (Bousquet et al. 2006). Estimating the contribution of different sources of emissions to the global $\mathrm{CH}_{4}$ budget, such as terrestrial (soils) and marine ecosystems (oceans, estuaries), and also the relative contribution of anthropogenic $\mathrm{CH}_{4}$ production (combustion of fossil fuels, forest burning, cattle rearing, rice fields) remains uncertain (Kirschke et al. 2013). 
$\mathrm{CH}_{4}$ emissions into the atmosphere vary between different natural sources. The world's oceans seem to play a modest role in the global atmospheric $\mathrm{CH}_{4}$ budget (Matthews 1994); however, this role may fluctuate over both spatial and temporal scales, and the extent of this variation remains unclear (Bates et al. 1996). Within aquatic systems, estimates of coastal $\mathrm{CH}_{4}$ content and fluxes are uncertain due to the lack of an adequate existing database (IPCC 2013). Estuaries and continental shelves appear to be responsible for ca. $75 \%$ of the oceanic $\mathrm{CH}_{4}$ emissions (Bange et al. 1994; Borges and Abril 2011), due to the fact that these highly productive areas favor the benthic-pelagic coupling, and the underlying sediments emit large quantities of $\mathrm{CH}_{4}$ (Borges et al. 2016).

The content and rate of exchange of dissolved $\mathrm{CH}_{4}$ with the atmosphere is determined by the balance between production and consumption processes, which in turn are regulated by environmental conditions, principally by organic matter availability and oxygen concentration (Wolfe 1971). $\mathrm{CH}_{4}$ is generally formed by methanogens during anaerobic organic matter degradation (Reeburgh 2007), or by methylotrophs (Sowers and Ferry 1983; Sun et al. 2011). $\mathrm{CH}_{4}$ formation via methylotrophy occurs by transformations and cycling of methyl compounds, mediated by bacterioplankton, such as methylphosphonate (MPn) (Karl et al. 2008), dimethylsulphoniopropionate (DMSP) (Damm et al. 2010), and dimethyl sulfide (DMS) (Florez-Leiva et al. 2013). In addition, $\mathrm{CH}_{4}$ can be consumed (oxidized) via aerobic methanothophy (Hanson and Hanson 1996), or when $\mathrm{O}_{2}$ is exhausted, $\mathrm{NO}_{3}{ }^{-}$ and $\mathrm{SO}_{4}{ }^{2-}$ act as electron acceptors (Valentine 2011).

The southern coast of Chile, from the latitudes of the Reloncaví fjord $\left(41^{\circ} \mathrm{S}\right)$ to Cape Horn $\left(55^{\circ} \mathrm{S}\right)$, covers an area of approximately $241,000 \mathrm{~km}^{2}$ and is characterized by an extensive coastline composed of numerous islands, fjords, sounds, basins, and gulfs (Lange 2012). Strong seasonal changes in climate variables (e.g., solar radiation, wind, and precipitation), as well as different physical regimens (mixing and circulation in the water column), influence biogeochemical dynamics and also provoke complex marine-terrestrialatmospheric interactions. This results in a marked seasonality of biological production, which generally peaks during spring-summer (González et al. 2010; Montero et al. 2011). This is the first study of $\mathrm{CH}_{4}$ distribution in northern Chilean Patagonia. This region is a quasi-uninhabited area with minimum human activity, thus minimal influences of eutrophication are expected. However, due to the expansion of intense aquaculture activities, some signals of perturbations have been observed in aquatic systems in the region (Iriarte et al. 2010). Oceanographically, this region could be considered as a transitional marine system, influenced by nutrient-rich and highsalinity oceanic subsurface waters, and nutrient-poor and lowsalinity surface freshwater (Valle-Levinson et al. 2007). The main objective of the present study is to describe for the first time the $\mathrm{CH}_{4}$ distribution in the region, and to determine the relative contribution of estuarine and marine sources of $\mathrm{CH}_{4}$ under the influence of a strong freshwater runoff, during the winter season in northern Chilean Patagonia.

\section{Methods}

\section{Characteristics of Study Sites}

The study area comprises the area from the Reloncaví fjord $\left(41^{\circ} 40^{\prime} \mathrm{S}\right)$ to the Guafo mouth $\left(43^{\circ} 30^{\prime} \mathrm{S}\right)$ (Fig. 1). The Reloncaví fjord is one of the most widely studied fjords in Chile (e.g., Castillo et al. 2016). It is $55 \mathrm{~km}$ long and $2-$ $3 \mathrm{~km}$ wide and receives freshwater discharge from the Petrohué (annual mean $\sim 280 \mathrm{~m}^{3-1}$ ) and the Puelo River (annual mean $\sim 650 \mathrm{~m}^{3} \mathrm{~s}^{-1}$ ). The Puelo River is the main supplier of freshwater to the system, with a mixed hydrological regime, presenting larger contributions from rain in the austral winter and snow melt in the austral spring (León-Muñoz et al. 2013). The Reloncaví fjord opens into the Reloncaví Sound, which is $\sim 450 \mathrm{~m}$ deep and is characterized by the absence of a sill at the mouth; the resulting depth of the system enables conditions for recirculation. This sound is connected within the Inner Sea of Chiloé (ISC), which includes the Ancud and Corcovado Gulf. The Corcovado Gulf is connected with the adjacent Pacific Ocean through a wide entrance, the Guafo mouth, through the Penas channel (to the South of Chiloé Island), while the Ancud Gulf is connected to the Pacific through the Chacao channel (north of Chiloé Island) (Fig. 1). In northern Patagonia, water circulation essentially follows a two-layer estuarine flow pattern (Sievers and Silva 2008); brackish water moves out superficially, and marine water enters predominantly through a subsuperficial layer in the Guafo mouth. Occasionally, wind-associated (Cáceres et al. 2002) and/or non-linear tidal effects (Valle-Levinson et al. 2007) can generate a three-layer circulation pattern, which consists of a thin surface layer flowing ocean-ward, a thick intermediate layer flowing inward, and a narrow bottom layer flowing oceanward.

\section{Sampling}

Samples were collected during the CIMAR 19 cruise (Cruceros de Investigación Marina CONA) at 15 stations along the Reloncaví fjord and the interior sea of Chiloé. The cruise took place from July 4 to July 17, 2013, on board the R.V. Cabo de Hornos. Continuous vertical profiles of temperature $\left(\mathrm{T}^{\circ} \mathrm{C}\right)$, salinity (PSU), density $\left(\mathrm{kg} \mathrm{m}^{-3}\right)$ (as derived variable, Sigma-t), and dissolved $\mathrm{O}_{2}(\mu \mathrm{M})$ were obtained using a conductivity, temperature, and depth (CTD) sensor. Seawater samples were collected using a SBE 911plus CTD unit (SeaBird Scientific) mounted on a 12-bottle rosette. The measurement of suspended particle concentrations and size was 
Fig. 1 Map of the study area in the Reloncaví Estuary and Interior Sea of Chiloé, Southern Chile. Sampling locations are included in a modified map from Yevenes et al. 2016

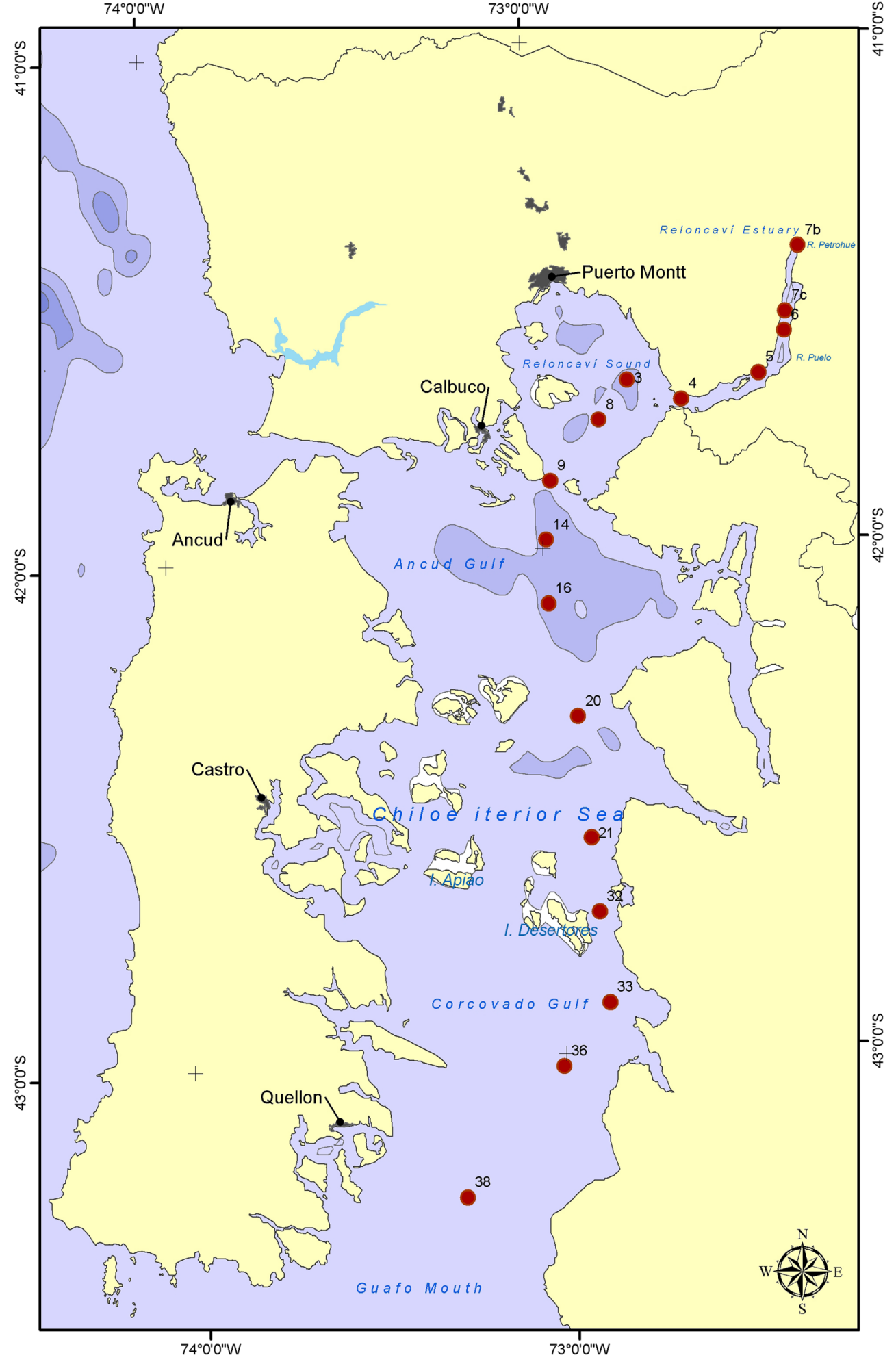

carried out with a LISST-25X (Sequoia Scientific Inc). This instrument functions through laser diffraction; when the laser beam encounters a particle, it scatters in a manner that is proportional to the particle's cross-sectional area; the LISST-25X is suitable for operations within a concentration range of approximately 1 to $2000 \mathrm{mg} \mathrm{L}^{-1}$. Within this range, the sensor is capable of calibrating sediment concentration regardless of particle color or size.

Water samples for $\mathrm{CH}_{4}$ and nutrients (sampled in this consecutive order) were obtained from 10 depths $(0,5,10,15,25,40$, $50,75,100$, and $200 \mathrm{~m}$ depth). Water samples for $\mathrm{CH}_{4}$ (triplicate) for each depth (one Niskin bottle per depth) were taken in 20-mL 
glass vials and poisoned with $\mathrm{HgCl}_{2}\left(0.1 \mathrm{~mL}\right.$ of saturated $\mathrm{HgCl}_{2}$ solution per vial). Subsequently, the vials were sealed with a butyl rubber septum and an aluminum cap to ensure gastight conditions, avoiding bubble formation, and stored in darkness at room temperature for 1 month, until laboratory analysis. Nutrient samples $\left(\mathrm{NO}_{3}{ }^{-}, \mathrm{NO}_{2}{ }^{-}, \mathrm{PO}_{4}{ }^{-3}\right.$, and $\left.\mathrm{Si}(\mathrm{OH})_{4}\right)$ were taken using $50-\mathrm{mL}$ syringes directly connected to the spigot of the Niskin bottle at each sample depth. Duplicate samples were collected and drawn through a $0.75-\mu \mathrm{m}$ glass fiber filter (GFF) adapted to the syringe, and then stored for 1 week until analysis in the laboratory.

\section{Chemical Analysis}

$\mathrm{CH}_{4}$ was analyzed via the generation of a 5-mL ultra-pure helium headspace into the vial using a gastight syringe. Subsequently, the gas and liquid phases were equilibrated within the vial at $40^{\circ} \mathrm{C}$. The procedure of equilibration entails the creation of a headspace, and the withdrawal of a seawater sample through a septum pierced with a double-needle liquidtransfer/gas-purge $(5 \mathrm{~mL}$ helium headspace and $15 \mathrm{~mL}$ of seawater). As the sample is withdrawn through one needle, gas (helium) enters through the other needle, which acts as a gas port and forms the headspace at atmospheric pressure.

Subsequently, $\mathrm{CH}_{4}$ was quantified in the vial headspace with Shimadzu 17A gas chromatograph using a flame ionization detector (FID) at $250^{\circ} \mathrm{C}$, through a capillary column GS$\mathrm{Q}$ at an oven temperature of $30^{\circ} \mathrm{C}$. A calibration curve was made using four concentrations for $\mathrm{CH}_{4}(0.5,1.78,2$, and $10 \mathrm{ppm}$, by Matheson standards). The FID detector responded linearly to these concentration ranges. The analytical error of the $\mathrm{CH}_{4}$ analyses was less than 5\%. The uncertainty of the measurements was calculated from the standard deviation of the triplicate measurements by depth. Samples with a variation coefficient higher than $10 \%$ were not included in the gas database. Nutrients $\left(\mathrm{NO}_{3}{ }^{-}, \mathrm{NO}_{2}{ }^{-}, \mathrm{PO}_{4}{ }^{-3}\right.$, and $\left.\mathrm{Si}(\mathrm{OH})_{4}\right)$ were analyzed using a Seal AA3 AutoAnalyzer, using the methodology described in Grasshoff et al. (1983).

\section{Data Analysis}

Saturation percentages of $\mathrm{CH}_{4}$ were calculated from the measured $\mathrm{CH}_{4}$ concentrations and using the estimations of atmospheric gas concentrations provided by NOAA (ftp://aftp. cmdl.noaa.gov/products/trends/ch4/ch4_mm gl.txt), based on in situ temperature and salinity records, and relating this to the equivalent $\mathrm{CH}_{4}$ solubility parameterization (Wiesenburg and GuinassoJr 1979). Air-sea $\mathrm{CH}_{4}$ exchange fluxes $F_{\text {air }}$ (in $\mu \mathrm{mol} \mathrm{day}{ }^{-1} \mathrm{~m}^{-2}$ ) were estimated from the following equation:

$$
F_{\text {air }}=k_{w}\left(\mathrm{C}_{w}-C_{\text {sat }}\right)
$$

where $k_{w}\left(\mathrm{~cm} \mathrm{~s}^{-1}\right)$ is the gas transfer velocity depending on wind speed, $C_{w}$ is the $\mathrm{CH}_{4}$ concentration (nM), and $C_{\text {sat }}$ is the $\mathrm{CH}_{4}$ concentration in equilibrium to the atmospheric concentration, cording to the solubility parameterization of Weiss and Price (1980), and assuming that the atmospheric $\mathrm{CH}_{4}$ concentration is $1803 \mathrm{ppb}$ (IPCC 2013). $k_{\mathrm{w}}$ was calculated using the parameterization of Nightingale et al. (2000):

$k_{w}=\left(9.25 \cdot 10^{-7} u+6.17 \cdot 10^{-7} u^{2}\right)\left(\frac{\mathrm{Sc}}{600}\right)^{-0.5}$

where $u$ is the wind speed $\left(\mathrm{cm} \mathrm{s}^{-1}\right)$ and Sc is the Schmidt number for $\mathrm{N}_{2} \mathrm{O}$. The Schmidt number relates the relationship between viscosity and the diffusion coefficient of $\mathrm{CH}_{4}$ in water, depending on the temperature and salinity of the seawater. For $\mathrm{N}_{2} \mathrm{O}$, the Schmidt number as a function of temperature $\left({ }^{\circ} \mathrm{C}\right)$ is given by Wanninkhof (1992):

$\mathrm{Sc}=230.1-151.15 \times T+4.7364 \times T^{2}-0.059431 \times T^{3}(3)$

Nightingale's parameterization shows a dependence between those of Liss and Merlivat (1986) and Wanninkhof (1992) and reduces the uncertainty of other parameterizations. The wind speed data was measured on board and normalized to $10 \mathrm{~m}$ height using the relationship of Garratt (1977). Wind speed was estimated as a moving 7-day average prior to the sampling period in order to smooth out short-term fluctuations and highlight longer-term trends. In the case of rivers and fjords, if the drag and current conditions are sufficiently high or exceed an order of magnitude of wind $\left(>10 \mathrm{~m} \mathrm{~s}^{-1}\right.$ in the fjord valley), surface currents must also be considered. In this case, it is not necessary to consider superficial currents, which were reported to be as low as $5 \mathrm{~cm} \mathrm{~s}^{-1}$ (even at maximum tidal currents; Valle-Levinson et al. 2007). Thus, surface current was not included in the estimation of gas transfer velocity $\left(k_{w}\right)$, as was the cases for estimates of $\mathrm{N}_{2} \mathrm{O}$ fluxes (Yevenes et al. 2016); however, this may underestimate $\mathrm{N}_{2} \mathrm{O}$ fluxes in the Reloncaví fjord. The mixed layer depth was calculated using a potential density-based criterion, defining it as the shallowest depth at which density increased by $0.02 \mathrm{~kg} \mathrm{~m}^{-3}$ from the sea surface value (Kara et al. 2003). Stratification was estimated using the Brunt-Väisälä frequency, which is used as a parameter to quantify the significance of stability and stratification in the water column.

In order to evaluate the variation between the two areas (estuarine and marine), the non-parametric multidimensional scaling (MDS) calculations were applied to physicochemical variables between 0 and $200 \mathrm{~m}$ depth (data was transformed to Log: $X+1)$, prior to the application of the Euclidian dissimilarity index. Then, an analysis of similarities (ANOSIM) was applied, with permutation of 9999 to determine statistical differences with a significance level of $p<0.05$, testing the null hypothesis of similarity between the areas. In addition, 
Spearman correlations (Rho) for salinity, $\mathrm{CH}_{4}$, nutrients, and particle variation in surface ( $>10 \mathrm{~m}$ depth) and subsurface (10-200 $\mathrm{m}$ depth) waters were used, due to the fact that some variables behaved as non-normal data. The threshold value for statistical significance was set as $p<0.05$. Data were processed using Primer 6.0 and SigmaStat 4.0. Spatial data were plotted using the Ocean Data View program 4.0 and SigmaPlot 10.0 .

\section{Results}

\section{Spatial Distribution of Physical and Biogeochemical Variables}

Physical and biogeochemical variables are summarized in Table 1 . The study area was divided into two layers, according to the vertical structure of the water column, i.e., two distinct layers: from 0 to $<5 \mathrm{~m}$ (surface layer), and from 10 to $200 \mathrm{~m}$ (subsurface layer). Also, two sections were allocated depending on the relative influence of fresh vs. marine water (according to temperature, salinity, and density). The sections comprise the Reloncaví fjord and the sound (Sts. 7b, 7c 6, 5, 4, 3, 8 , and 9; hereafter the estuarine area), and the ISC comprise the Ancud and Corcovado Gulf(Sts. 14, 16, 20, 21, 32, 33, 36, 38; hereafter referred to as marine area). This division was previously established for the study area by Yevenes et al. (2016), taking into account the distribution of temperature, salinity, and Sigma-t. These spatial patterns were validated by multidimensional scaling (MDS) analysis applied to physicochemical (i.e., $\mathrm{T}^{\circ} \mathrm{C}, \mathrm{S}$, Sigma-t, and stability) and biogeochemical variables, including dissolved $\mathrm{CH}_{4}$, particles, and nutrients (data not shown).

There is a clear separation between the outflow of colder and brackish surface water and the inflow of more saline and warmer subsurface water, which affects the stability of the water column. The stability, or BruntVäisälä frequency, is presented in Fig. 2a and shows a fluctuation from 0.1 to 115 cycle $^{-1}$, which peaks in the surface water (predominantly between 5 and $10 \mathrm{~m}$ depth) and then decreases to relatively steady values in the subsurface layer $\left(0.1\right.$ to 10 cycles $\left.\mathrm{h}^{-1}\right)$. The maximum frequency marked a notable stratification in the surface layer, which creates a strong shear stress that may facilitate drag and the accumulation of particles (Fig. 2b). Particle concentration decreased exponentially with depth, with the highest values at the surface in the estuarine area, where the particle concentration reached up to $424.6 \mathrm{mg} \mathrm{L}^{-1}$. Also, the largest particle sizes were registered in the surface layer, measuring from 0.02 to $4308 \mu \mathrm{m}$ (Fig. 2c); conversely in subsurface waters, the concentration and size were one order of magnitude less than in the subsurface layer. In the marine area, both the concentration and size of particles in the surface layer were lower than in the estuarine area (mean $\pm \mathrm{SD}$ $56.64 \pm 56.08 \mathrm{mg} \mathrm{L}^{-1}$ and $13.19 \pm 15.78 \mu \mathrm{m}$, respectively), and the concentration and size reduced exponentially with depth. In the estuarine area, the particle size ratio between the surface and subsurface layers showed a 771-fold variation, whereas in the marine area the ratio was 3 -fold, suggesting that in the estuarine area the particles have a continental origin.

Figure 3 shows the cross section distribution of $\mathrm{CH}_{4}(\mathrm{nM})$ (Fig. 3a) along with dissolved $\mathrm{O}_{2}(\mu \mathrm{M})$ (Fig. 3b) and $\mathrm{Si}(\mathrm{OH})_{4}$ $(\mu \mathrm{M})$ (Fig. 3c). Dissolved $\mathrm{CH}_{4}$ showed a concentration range from 7.65 to $151.4 \mathrm{nM}$, following similar distributions to those observed for brackish water and particles. A maximum $\mathrm{CH}_{4}$ concentration of $151.1 \mathrm{nM}$, equivalent to $1403 \%$ saturation, was found superficially ( $1 \mathrm{~m}$ depth) at St. $7 \mathrm{~b}$ (located in the downstream sections of the Petrohué River) and at the following stations that are under riverine influence; towards the Reloncaví Sound and the ISC, $\mathrm{CH}_{4}$ levels decreased. Marked differences in $\mathrm{CH}_{4}$ content were also observed between the surface and subsurface layers, with mean \pm SD values of $52.20 \pm 46.49$ and $22.75 \pm 4.36 \mathrm{nM}$, respectively (Table 1). In the ISC, $\mathrm{CH}_{4}$ showed a more uniform distribution in both the surface and subsurface layers, with mean $\pm \mathrm{SD}$ values of $19.84 \pm 6.20$ and $18.18 \pm 6.08 \mathrm{nM}$, respectively.

$\mathrm{CH}_{4}$ fluxes across the air-sea interface, estimated from surface $\mathrm{CH}_{4}$ levels and wind parameterization, ranged from 22.2 to $136 \mu \mathrm{mol} \mathrm{m}{ }^{-2} \mathrm{day}^{-1}$. As expected, the estuarine area had higher levels of $\mathrm{CH}_{4}$ exchange to the atmosphere, ranging from 23.9 to $136 \mu \mathrm{mol} \mathrm{m}^{-2} \mathrm{day}^{-1}$. There was a decrease in the $\mathrm{CH}_{4}$ emissions towards the marine environment, with a narrower extent of efflux, from 22.2 to $46.6 \mu \mathrm{mol} \mathrm{m}^{-2} \mathrm{day}^{-1}$.

The dissolved $\mathrm{O}_{2}$ fluctuated between 128 and $379 \mu \mathrm{M}$, with the lowest concentrations in the subsurface layer of the estuary and gradually and lightly increasing towards the ISC (Gulf of Corcovado) (Fig. 3b). Within the ISC, $\mathrm{O}_{2}$ distribution was homogenous throughout the water column, with values of around $250 \mu \mathrm{M}$. $\mathrm{NO}_{3}{ }^{-}$and $\mathrm{PO}_{4}{ }^{-3}$ distributions have been reported by Yevenes et al. (2016) during the same period; however, there are no records for $\mathrm{Si}(\mathrm{OH})_{4}$. The latter ranged from 13.2 to $111 \mu \mathrm{M}$, with the highest concentrations observed in the surface water of the Reloncaví fjord, averaging $61.8 \pm 38.8 \mu \mathrm{M}$, which contrasts with the lowest values in surface waters, observed in the ISC (mean $\pm \mathrm{SD}$ $22.49 \pm 7.54 \mu \mathrm{M})$ (Fig. 3c).

Table 2 shows Spearman correlations for variables that could explain $\mathrm{CH}_{4}$ distribution. In surface waters, a significant negative relationship was found between salinity vs. $\mathrm{CH}_{4}$ $(p<0.00)$ and salinity vs. $\mathrm{Si}(\mathrm{OH})_{4}(p<0.00)$, verifying that during winter, freshwaters have a high $\mathrm{CH}_{4}$ and $\mathrm{Si}(\mathrm{OH})_{4}$ content; this relationship was not significant in marine water. Remarkably, $\mathrm{CH}_{4}$ levels in the surface of the estuary showed a positive correlation with particle size $(p<0.00)$ and 


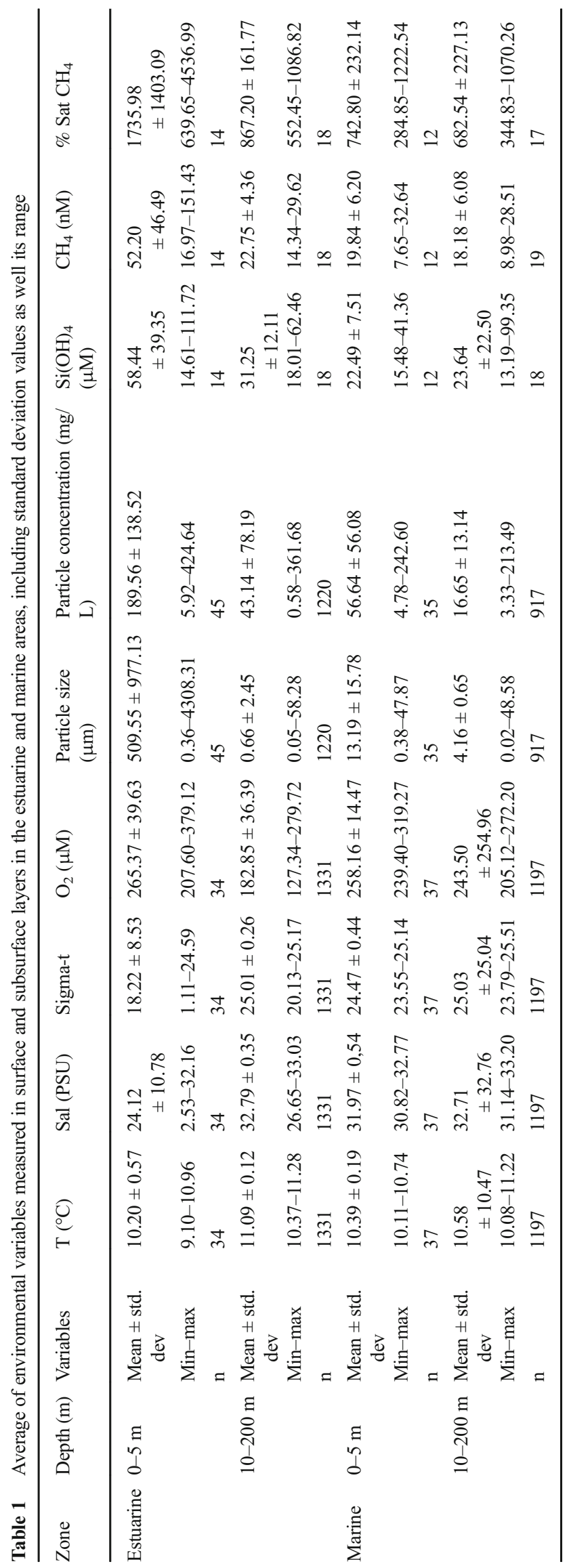


concentration $(p<0.00)$ (Table 2). However, these correlations were found neither in the subsurface water of the estuarine area nor in the marine area.

\section{Vertical Distribution of Gases and Nutrients}

Figure 4 presents typical particle (concentration and size), nutrient $\left(\mathrm{Si}(\mathrm{OH})_{4}\right.$ and $\left.\mathrm{NO}_{3}{ }^{-}\right)$, and gas $\left(\mathrm{O}_{2}\right.$ and $\left.\mathrm{CH}_{4}\right)$ profiles from selected stations. We selected a station from the Reloncaví fjord (St. 6; Fig. 4a), in the Reloncaví Sound (St. 9, Fig. 4b), and in the northern (St. 20; Fig. 4c) and southern sections of the ISC (St. 38 close to Guafo mouth). The vertical distribution of biogeochemical variables was clearly in line with the double-layer structure in the estuarine area, which in turn was predominantly controlled by the physical structure of the estuary. This structure was influenced by river discharge, characteristically low in $\mathrm{NO}_{3}{ }^{-}$but high in $\mathrm{O}_{2}, \mathrm{CH}_{4}$, particles, and $\mathrm{Si}(\mathrm{OH})_{4}$ load (Fig. 4a, b). Conversely, in the ISC, profiles are smoother (Fig. 4c, d) and mainly influenced by the entry of oceanic water masses through the Guafo mouth, such a subantarctic water (SAAW). Additionally, a deep equatorial water mass (ESSW) rich in $\mathrm{NO}_{3}{ }^{-}$and relatively lower $\mathrm{O}_{2}$ was observed.

\section{Discussion}

\section{Hydrographic Setting}

The Patagonia fjord region is composed by a large number of fjords, sounds, and basins and is subjected to strong seasonal climatic changes (e.g., solar radiation, wind, and precipitation) as well as different physical regimens (mixing and/or stability of the water column), imposing an external influence on biogeochemical cycles. There is a notably high annual rainfall in the fjord region (1000-7000 $\mathrm{mm}$ year $\left.^{-1}\right)$, and associated high mean annual river discharges, which reach a maxima in winter $\left(\sim 1500-3500 \mathrm{~m}^{3} \mathrm{~s}^{-1}\right)$ (Rubio-Álvarez and McPhee 2010). This greatly enhances the supply of terrigenous sediment and nutrients (Iriarte et al. 2010). These conditions occur in the Reloncaví fjord, where freshwater discharge reaches a maxima in wintertime (July) with levels up to $\sim 1250 \mathrm{~m}^{3} \mathrm{~s}^{-1}$ (León-Muñoz et al. 2013), producing a strong stratification (Fig. 2a) predominantly due to the vertical gradient in salinity (Yevenes et al. 2016).

Thus, circulation in the Reloncaví fjord during the austral winter predominantly follows a two-layer estuarine circulation pattern mainly controlled by freshwater discharges (ValleLevinson et al. 2007; Letelier et al. 2011). As the surface water flows ocean-ward, it progressively increases in salinity and $\mathrm{NO}_{3}{ }^{-}$and $\mathrm{PO}_{4}{ }^{-3}$ content (Yevenes et al. 2016), but decreases slightly in $\mathrm{O}_{2}$ and $\mathrm{Si}(\mathrm{OH})_{4}$ content (Fig. 3b, c). The subsurface layer (10-200 m), which is of marine origin, flows into the
ISC through the Guafo mouth. It is mainly composed of SAAW, with a high salinity (32.5-34.0), and with $\mathrm{NO}_{3}{ }^{-}$and $\mathrm{PO}_{4}{ }^{-3}$ ranging from 1.2 to 1.6 and 10 to $20 \mu \mathrm{M}$, respectively (Yevenes et al. 2016). The $\mathrm{O}_{2}$ content was relatively low in comparison with the brackish waters (Fig. 3b) and has typical SAAW values, similar to those found in the Guafo mouth (Silva and Neshyba 1979).

Since the SAAW flows towards the head of the fjord, it progressively mixes with the outflowing fresher estuarine water, creating modified subantarctic water (MSAAW), which has been defined as having intermediate salinities of $~ 31-33$ (Sievers and Silva 2008). Although studies of dissolved $\mathrm{CH}_{4}$ distribution in adjacent ocean water (offshore Chiloé Island, $41^{\circ} 50^{\prime} \mathrm{S}$ ) are currently not available, some existing data (Farías non-published data) indicate that $\mathrm{CH}_{4}$ levels in SAAW are approximately 5-10 $\mathrm{nM}$ (Fig. 3a). Thus, $\mathrm{CH}_{4}$ concentrations over the entire water column in the ISC are lightly enriched in $\mathrm{CH}_{4}$ relative to the adjacent open ocean. These results may be due to circulation (longer water residence time) and/or mixing with estuarine water. Some in situ $\mathrm{CH}_{4}$ production may be occurring, given that the ISC is shallower and receives more organic matter from continental runoff and salmon aquaculture activities (Iriarte et al. 2010) compared to the open sea.

$\mathrm{CH}_{4}$ exchange across the air-sea interface reflects the $\mathrm{CH}_{4}$ content in the surface layer. The highest $\mathrm{CH}_{4}$ effluxes were observed in the upstream stations of the Reloncaví fjord, and the emissions decreased as salinity increased. In comparison with other estuaries and coastal areas, the Reloncaví fjord is a moderate areal source of $\mathrm{CH}_{4}$, ranging from 23.9 to $136 \mu \mathrm{mol} \mathrm{m}{ }^{-2} \mathrm{day}^{-1}$. The fluxes were two times greater than effluxes from open oceans (Holmes et al. 2000) and from continental shelves (Bange 2006; US EPA 2010). This range is very modest compared to rivers where maximum values are up to several micromolars (Stanley et al. 2016; Borges et al. 2015a, 2015b). There are no existing studies of seasonal behavior for this area, but estimated fluxes in winter were lower than those registered in the eutrophic inner estuaries of Northern Europe (Bange 2006). In addition, if the results from this study can be extrapolated to other estuarine systems within the northern Patagonia Region, it would signify that this region represents a large natural source of $\mathrm{CH}_{4}$ (Middelburg et al. 2002; Borges and Abril 2011). It is important to note that due to the remote region of the study sites, the seasonal behavior is not fully understood; however, it is clear that temperature and biological productivity increases in the summer (due to greater solar radiation), which may in turn increase the in situ production of methane.

\section{Autochthonous Methane Origin in the Reloncaví Fjord}

The origin of autochthonous $\mathrm{CH}_{4}$ is thought to be a result of in situ production via methanogenesis within anoxic sediments 

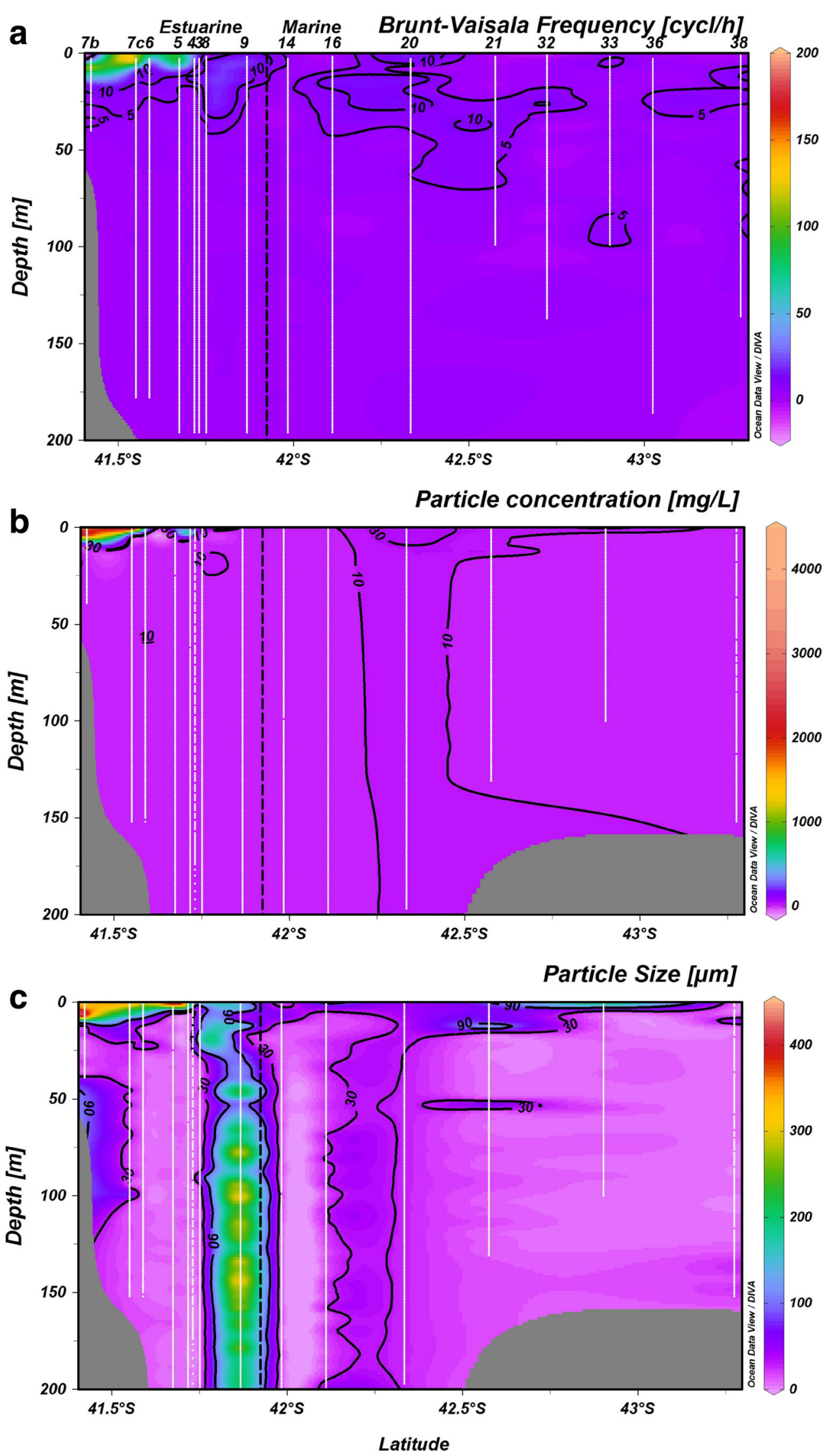
4 Fig. 2 Cross section distribution of oceanographic variables and parameter from the fjord Reloncaví (St. 7b) to the Gulf of Corcovado (St. 38), including a Brunt-Väisälä frequency (cycle/h). b Particle concentration $(\mathrm{mg} / \mathrm{L})$. c Size particles $(\mu \mathrm{m})$. Vertical striped lines separated estuarine (Sts. 7b, 7c, 6, 5, 4, 3, 8, and 9) from marine area (Sts. 14, 16, 20, 21, 32, 33, 36, 38)

(Borges et al. 2016), or alternatively within particles that act as anoxic micro-niches while suspended in the oxygenated water column (Ploug et al. 1997). In the majority of coastal systems, surface $\mathrm{CH}_{4}$ is produced in the anoxic sediments of fjords and reaches the surface through upward transportation (Borges and Abril 2011; Borges et al. 2016). However, this is not the case for the Reloncaví fjord system, as within the estuarine stations, the bottom waters and underlying sediment did not exhibit consistently higher $\mathrm{CH}_{4}$ levels compared to surface waters (Fig. 4a, b), as expected if the contribution of surface $\mathrm{CH}_{4}$ came via diffusion from anoxic sediments. Since the water column is relatively well oxygenated (Fig. 3b), it is expected that aerobic $\mathrm{CH}_{4}$ production within the water column is the dominant mechanism of production in surface water, where the majority of $\mathrm{CH}_{4}$ is concentrated (Fig. 3a). It seems that either various microbial pathways are involved in this production (Karl et al. 2008; Grossart et al. 2011) or that this occurs via anaerobic $\mathrm{CH}_{4}$ production in anoxic microniches within a generally oxic environment.

Thus, the $\mathrm{CH}_{4}$ content in surface waters could be related to microbial processes taking place in suspended particles (of both allochthonous and autochthonous origin). In this sense, the expected stratification (Fig. 2a) could lead to the accumulation of particles (Fig. 2b, c) and $\mathrm{CH}_{4}$ (Fig. 3a). In addition, in Chilean fjords, the horizontal buoyancy input resulting from freshwater runoff has an important effect on the primary production of algae, which in this case are isolated from key nutrient sources (i.e., the nutrients trapped below the pycnocline), thus stratification leads to biomass accumulation. As a result, aerobic metanogenesis could be directly stimulated via the generation of substrates by phytoplankton, or indirectly via bacterioplankton, which appears to facilitate the recycling of organic matter and the production of $\mathrm{CH}_{4}$. Grossart et al. (2011) observed methanogenic Archaea, which are generally attached to photoautotrophs, and facilitated the anaerobic growth and direct transfer of substrates for $\mathrm{CH}_{4}$ production.

The velocities of settling particles are reduced as a result of stratification; this indicates the cause of the increase in observed particle densities in the surface layer of the estuary. Increased presence of large particles accumulated at the surface is likely to be due to the deceleration in downward flux within strong Sigma-t gradients (salinity), caused by the mixing of brackish water and seawater, and also by the shear stress caused by estuarine circulation patterns (Letelier et al. 2011; Valle-Levinson et al. 2007). Furthermore, this study has identified a wide range of particle sizes $(0.02$ to $4302 \mu \mathrm{m})$, owing to larger-sized particles $(>300 \mu \mathrm{m})$ in surface waters within the upstream stations of the Reloncaví fjord (Fig. 2c). This suggests that particles are not only of marine origin, but they are also input from soils as a result of precipitation. Previous studies indicate that surface sediments of the Reloncaví, Puyuhuapi, and Aysén fjords have high organic carbon contents (i.e., >3\%; Silva et al. 2011), with significant inputs by major rivers (i.e., Puelo, Cisnes, and Aysén rivers). The allochthonous carbon content in the surface sediments of these fjords (estimated with $\delta^{13} \mathrm{C}$ ) ranges between 50 and $90 \%$, decreasing to less than $10 \%$ towards the oceanic area (Silva et al. 2011).

In most permanent and seasonally stratified oceanic waters, the maximum $\mathrm{CH}_{4}$ concentration (Figs. 3a and 4) is consistently observed to coincide with increased particle accumulation at pycnoclines (Sieburth and Donaghay 1993). Thus, it is believed that these particles may act as anoxic microenvironments, as they are chemical hotspots providing both organic and inorganic substrates to sustain the anaerobic metabolism of pelagic microbiota (Ploug et al. 1997). Indeed, both autochthonous (plankton) and/or allochthonous (seston) particles can be colonized by decomposers (heterotrophs), which include a proportion of methanogens. Sieburth and Donaghay (1993) reported the existence of methanogenic bacterial consortia that can use methylated amines to create reduced micro-niches in oxygenated seawater and produce both $\mathrm{CH}_{4}$ and $\mathrm{HS}^{-}$in the upper ocean. Methanogenic substrates such as monomethylamine and trimethylamine, which are constituents of diatoms, dinoflagellates, and flagellate phytoplankton species, could be involved in $\mathrm{CH}_{4}$ production during grazing by copepods (De Angelis and Lee 1994). In addition, methylotrophic methanogens that use the products generated from the degradation of methylated amine in microalgae could be responsible for the production of $\mathrm{CH}_{4}$ (Oremland et al. 1982; King et al. 1983; King 1984). Recently, this mechanism has been described using substrates as DMSP (Damm et al. 2010) and also DMS (Florez-Leiva et al. 2013).

$\mathrm{CH}_{4}$ content and emissions in aquatic systems reflect the characteristics of the surrounding catchment area, such as topography, soil type, and texture, as well as land use and other anthropogenic activities (Jones and Mulholland 1998), and also the features of the adjacent marine system, such as tidal and wave movements and geomorphology (US EPA 2010). In general, higher $\mathrm{CH}_{4}$ content and effluxes have been found in streams and rivers surrounded by peatlands and flooded forests (Jones and Mulholland 1998; Hope et al. 2001; Borges et al. 2015a, 2015b) compared to those with adjacent marine systems. The highest levels of $\mathrm{CH}_{4}$ measured in this study were located superficially at a salinity of less than 5, at upstream stations (Fig. 3a; Yevenes et al. 2016), with a $\mathrm{Si}(\mathrm{OH})_{4}$ of $109 \mu \mathrm{M}$, and a particle concentration and size of $500 \mathrm{mg} \mathrm{L}^{-1}$ and $300 \mu \mathrm{m}$, respectively (Figs. 3c and 2b, c). 

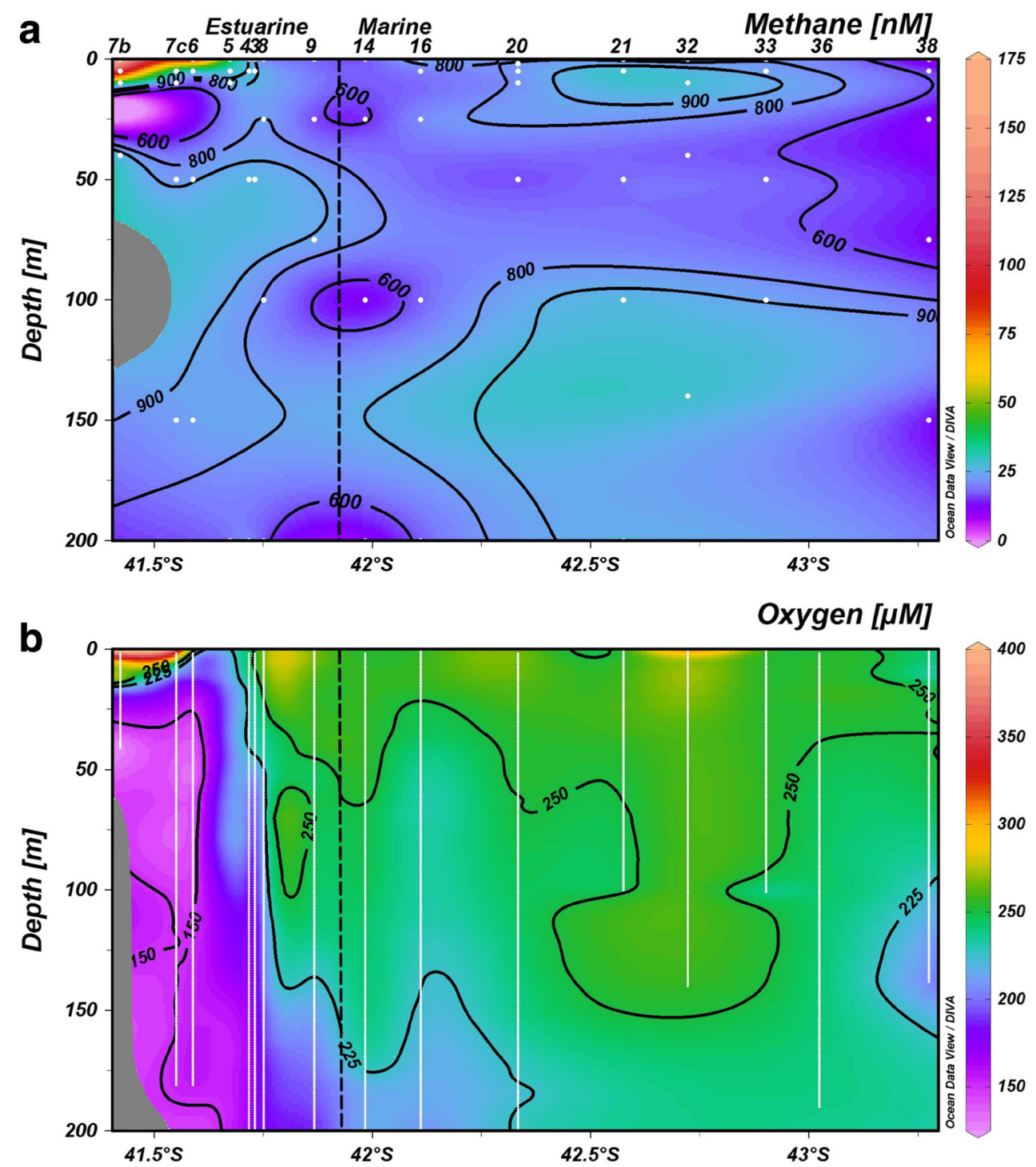

Silicate $[\mu M]$

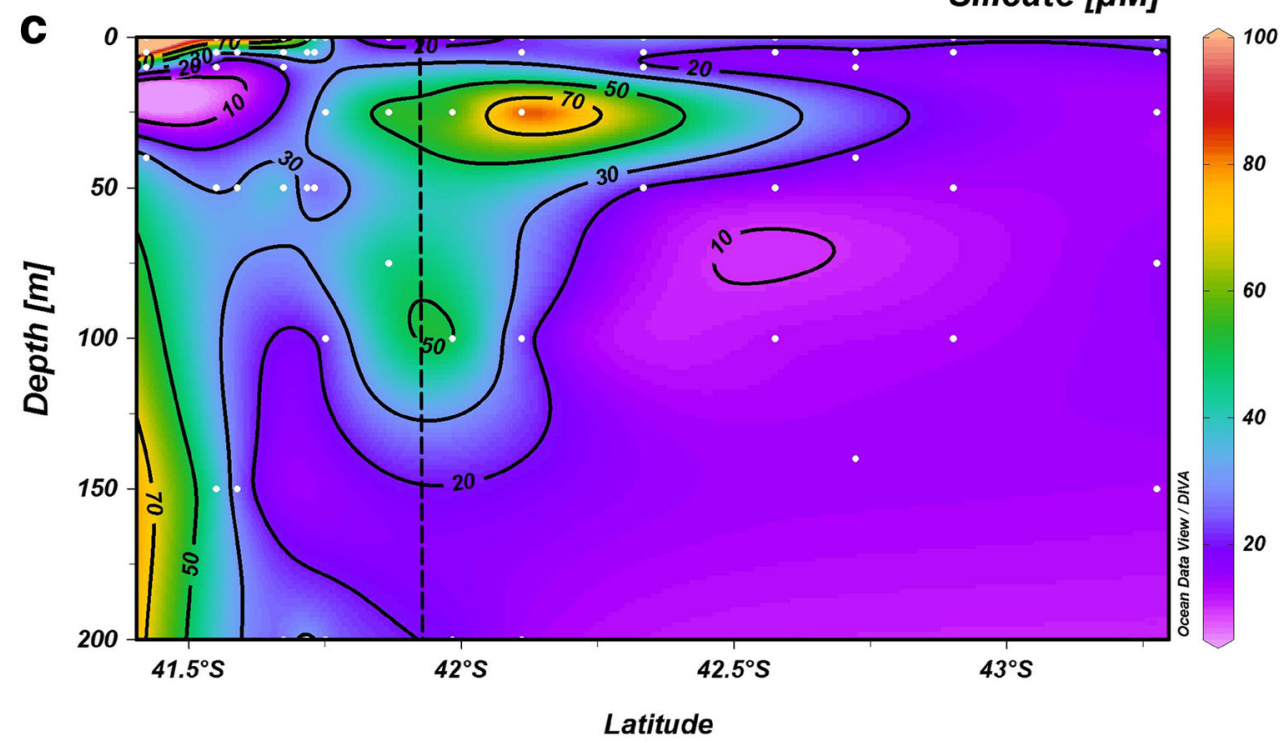


Fig. 3 Cross section distribution of the biogeochemical conditions from the Reloncaví fjord (St. 7b) to the Gulf of Corcovado (St.38). a Methane $(\mathrm{nM})$; isolines correspond to \% saturation. b Dissolved oxygen $(\mu \mathrm{M})$. c Silicate $(\mu \mathrm{M})$. Vertical lines separated estuarine (Sts. 7b, 7c, 6, 5, 4, 3, 8, and 9) from marine area (Sts. 14, 16, 20, 21, 32, 33, 36, and 38)

Also, a positive correlation was observed between $\mathrm{Si}(\mathrm{OH})_{4}$ and salinity in the estuarine area (Table 2), suggesting that water from continental runoff contributes high levels of $\mathrm{Si}(\mathrm{OH})_{4}$ into the Reloncaví fjord. Indeed, northern Chilean Patagonia is characterized by andosol-type soil, which affects dissolved $\mathrm{Si}(\mathrm{OH})_{4}$ concentrations in the river system and potentially explains the exceptionally high regional rates of biogenic $\mathrm{Si}(\mathrm{OH})_{4}$ production (Vandekerkhove et al. 2016). In addition, $\mathrm{Si}(\mathrm{OH})_{4}$ is well correlated with both particle concentration and dissolved $\mathrm{CH}_{4}$ (Table 2), indicating that the majority of the particles suspended in the water column originate from continental runoff.

The extent of supply coming from continental runoff (both laterally and along the systems) depends on the vegetation type and adjacent soils; both factors stimulate the production of microbial $\mathrm{CH}_{4}$. Plants mediate $\mathrm{CH}_{4}$ production as they constitute $\mathrm{C}$ substrates as products of photosynthesis, derived from living plants and/or labile organic carbon (Ding et al. 2002, 2005; Tsuruta and $\mathrm{Li}$ 2003). $\mathrm{CH}_{4}$ is accumulated in the interstices of soils and then transported to the atmosphere by plants through the parenchyma system or by lateral diffusion and runoff from saturated soils. Thus, soils may be important in determining $\mathrm{CH}_{4}$ levels in rivers and estuarine systems (De Angelis and Miller 1987; Sansone et al. 1999). As previously mentioned, Chile has one of the highest global incidences of peatlands, dominated by Sphagnum magellanicum, (Joosten and Clarke 2002). Although Chile lacks a detailed register of peatlands, they are predominantly distributed from the Los Lagos $\left(41^{\circ} \mathrm{S}\right)$ to the Magellan $\left(55^{\circ} \mathrm{S}\right)$ regions. It should also be noted that they are being exploited as carbon energy source (Valdés-Barrera et al. 2012). $\mathrm{CH}_{4}$ is released from peat columns as a result of recently fixed (young) carbon, and production rates can be substantially stimulated through addition of labile organic carbon at a low $\mathrm{pH}$ (Lai 2009), as demonstrated in these soils by Filipová et al. (2010).

It is also important to consider the type of land use; however, it remains uncertain if land use has significant influence on $\mathrm{CH}_{4}$ levels in rivers. For example, where land use is mainly forest and/or fertilized agriculture, no systematic differences were observed in $\mathrm{CH}_{4}$ content (US EPA 2010). In general, nitrogen fertilizers are not extensively used on Patagonian soils (non-agricultural activities), therefore the $\mathrm{N}$ and $\mathrm{P}$ nutrient load in the study area should be very low in comparison to rivers and estuaries in the Northern Hemisphere, many of which are subjected to increasing levels of organic matter input and nutrient enrichment (Bange 2006). In addition, within the study area, the Los Lagos region, there is a low-moderate level of cattle rearing, evident from low levels of
Table 2 Spearman correlations of the same variables measured in both surface and subsurface layers, including the estuarine and marine area

\begin{tabular}{|c|c|c|c|c|c|c|c|c|c|c|c|c|}
\hline & \multicolumn{3}{|c|}{ Sal (PSU) } & \multicolumn{3}{|c|}{$\begin{array}{l}\text { Particle size } \\
(\mu \mathrm{m})\end{array}$} & \multicolumn{3}{|c|}{$\begin{array}{l}\text { Particle } \\
\text { concentration } \\
(\mathrm{mg} / \mathrm{L})\end{array}$} & \multicolumn{3}{|c|}{$\begin{array}{l}\mathrm{Si}(\mathrm{OH})_{4} \\
(\mu \mathrm{M})\end{array}$} \\
\hline & Rho & $p$ & $n$ & Rho & $p$ & $n$ & Rho & $p$ & $n$ & Rho & $p$ & $n$ \\
\hline $\begin{array}{l}\mathrm{CH}_{4}(\mathrm{nM}) \\
\quad \text { estuarine } \\
0-5 \mathrm{~m}\end{array}$ & $-0.97^{\mathrm{a}}$ & 0.00 & 6 & $0.77^{\mathrm{a}}$ & 0.00 & 13 & $0.74^{\mathrm{a}}$ & 0.00 & 13 & $0.86^{\mathrm{a}}$ & 0.00 & 14 \\
\hline $\begin{array}{l}\mathrm{CH}_{4}(\mathrm{nM}) \\
\quad \text { estuarine } \\
10-200 \mathrm{~m}\end{array}$ & -0.46 & 0.06 & 17 & 0.16 & 0.55 & 16 & 0.45 & 0.08 & 16 & -0.37 & 0.12 & 18 \\
\hline $\begin{array}{l}\mathrm{CH}_{4}(\mathrm{nM}) \text { marine } \\
0-5 \mathrm{~m}\end{array}$ & -0.28 & 0.59 & 6 & -0.54 & 0.08 & 11 & -0.38 & 0.24 & 13 & 0.16 & 0.61 & 12 \\
\hline $\begin{array}{c}\mathrm{CH}_{4}(\mathrm{nM}) \text { marine } \\
10-200 \mathrm{~m}\end{array}$ & -0.29 & 0.26 & 17 & 0.03 & 0.90 & 15 & 0.11 & 0.70 & 15 & 0.03 & 0.90 & 15 \\
\hline $\begin{array}{l}\mathrm{Si}(\mathrm{OH})_{4}(\mu \mathrm{M}) \\
\quad \text { estuarine } \\
0-5 \mathrm{~m}\end{array}$ & $-0.79^{\mathrm{a}}$ & 0.00 & 14 & $0.83^{\mathrm{a}}$ & 0.00 & 13 & $0.76^{\mathrm{a}}$ & 0.00 & 13 & & - & \\
\hline $\begin{array}{l}\mathrm{Si}(\mathrm{OH})_{4}(\mu \mathrm{M}) \\
\quad \text { estuarine } \\
10-200 \mathrm{~m}\end{array}$ & -0.19 & 0.46 & 18 & $0.56^{\mathrm{a}}$ & 0.02 & 16 & 0.16 & 0.56 & 16 & & - & \\
\hline $\begin{array}{l}\mathrm{Si}(\mathrm{OH})_{4}(\mu \mathrm{M}) \\
\quad \text { marine } 0-5 \mathrm{~m}\end{array}$ & -0.27 & 0.39 & 12 & $0.70^{\mathrm{a}}$ & 0.02 & 11 & $0.72^{\mathrm{a}}$ & 0.01 & 11 & & - & \\
\hline $\begin{array}{l}\mathrm{Si}(\mathrm{OH})_{4}(\mu \mathrm{M}) \\
\text { marine } \\
10-200 \mathrm{~m}\end{array}$ & -0.37 & 0.14 & 17 & 0.34 & 0.22 & 15 & 0.06 & 0.80 & 15 & & - & \\
\hline
\end{tabular}

${ }^{\mathrm{a}}$ Denotes significant correlations 


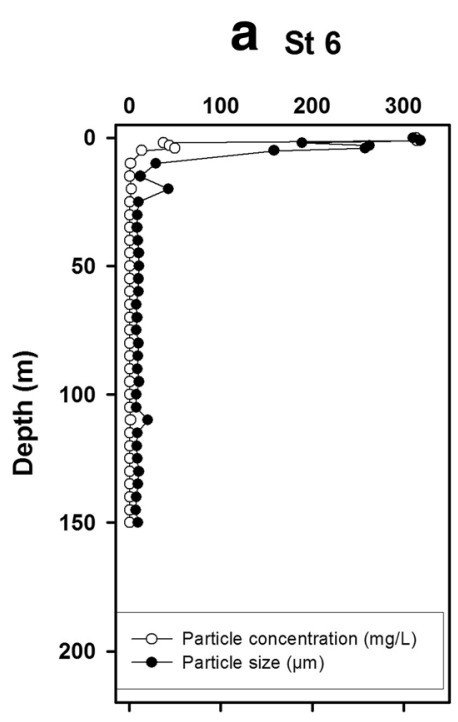

b st 9

C St 20

St 38
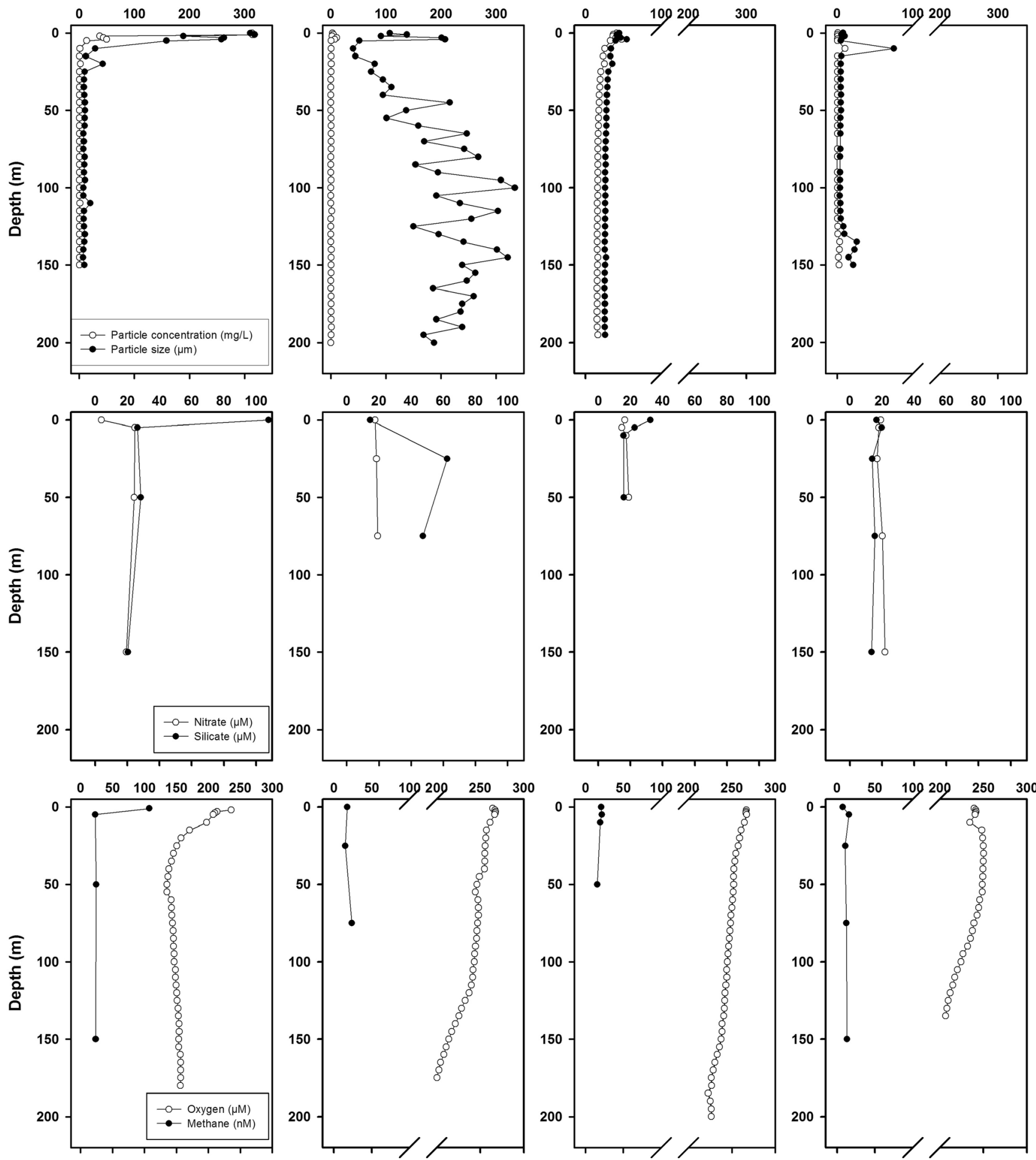

Fig. 4 Vertical distribution of a particles (concentration and size), b nutrients $\left(\mathrm{NO}_{3}{ }^{-}\right.$and $\left.\mathrm{Si}(\mathrm{OH})_{4}\right)$, and $\mathbf{c}$ gases (oxygen and methane) at selected stations from the fjord, sound, and the ISC (basin). Selected
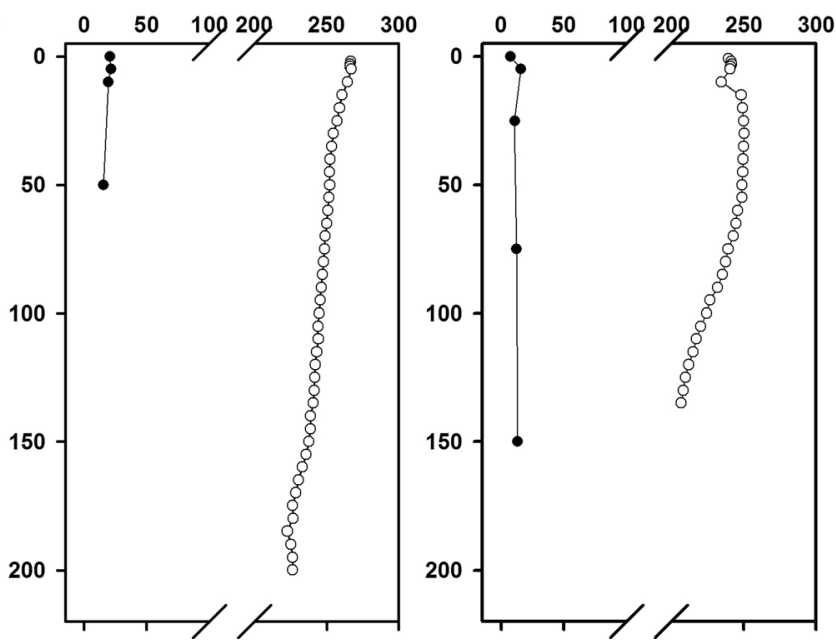

stations from ISC were separated by Islands Desertores-Apiao $(<100 \mathrm{~m})$ located at Ancud and Corcovado Gulf, respectively

Northern Chilean Patagonia has a low impact from urban observed ammonia emission (Martínez-Lagos et al. 2010), which is directly related to human activities. settlements. However, the city of Puerto Montt, located at the 
northern end of the Reloncaví Sound, is currently undergoing fast demographic growth, associated with the development of economic activities, especially with industries utilizing the natural resources that are locally available (predominantly aquaculture activities; Subpesca 2016). Thus, high levels of by-products from salmon and shellfish farming (surplus feed and/or feces) might affect the $\mathrm{O}_{2}$ content in stations located downstream of the estuary as a result of organic matter degradation in water and surface sediments (Iriarte et al. 2010; Tapia and Giglio 2010), along with a long water flushing time (Valle-Levinson et al. 2007), which favors the accumulation of larger-sized particles that apparently stimulate additional $\mathrm{O}_{2}$ consumption.

Aquaculture activities lead to an increased input of nitrogenous compounds (mainly ammonium and urea) and also result in feed additions (particles) below coastal salmon farms; however, this does not seem to stimulate $\mathrm{CH}_{4}$ production. Surprisingly, in the Reloncaví Sound, $\mathrm{CH}_{4}$ undergoes increased consumption relative to the surrounding water column (contrary to expected results of $\mathrm{CH}_{4}$ accumulation), suggesting that $\mathrm{CH}_{4}$ depletion is due to methanotrophy (Fig. 3a). This is contrary to the observed results for $\mathrm{N}_{2} \mathrm{O}$, where aquaculture favors $\mathrm{N}_{2} \mathrm{O}$ production processes, such as nitrification (Yevenes et al. 2016), also including seasonal phytoplankton blooms and the growth of harmful algal blooms (Arzul et al. 1999; Iriarte et al. 2005).

\section{Conclusions}

The station at the head of the Reloncaví fjord had a high $\mathrm{CH}_{4}$ content and efflux; also, the relationship between $\mathrm{CH}_{4}$, salinity, and $\mathrm{Si}(\mathrm{OH})_{4}$ indicates that most of the $\mathrm{CH}_{4}$ comes from continental runoff. With regards to the in situ $\mathrm{CH}_{4}$ production, it appears that the sediments are not an important source; however, some $\mathrm{CH}_{4}$ accumulation was observed in the pycnoclines of the estuarine zone, where a particle accumulation also occurs. This pattern indicates the presence of aerobic methanogenesis processes. The marine area associated with the ISC has increased the $\mathrm{CH}_{4}$ content compared to the offshore ocean; however, this is comparatively low with respect to estuarine waters, suggesting that $\mathrm{CH}_{4}$ content in the ISC responds to mixing with freshwater rich in $\mathrm{CH}_{4}$, along with some in situ production, with a longer water residence time in the ISC. Moreover, signals of increased eutrophication are observed from human activities; however, there is no evidence that this leads to an increase in the generation of $\mathrm{CH}_{4}$.

Acknowledgements This research was funded by the National Oceanographic Committee (Comité Oceanográfico Nacional) (CONA) and the Chilean Navy, as part of the multidisciplinary project CIMAR 19. This is a contribution supported by FONDECYT no. 1161138 (Laura Farías) and CONICYT/FONDAP program no. $1511009\left(\mathrm{CR}^{2}\right)$. Technical support from the laboratory of Isotopic Biogeochemistry (UdeC) is also appreciated.

Open Access This article is distributed under the terms of the Creative Commons Attribution 4.0 International License (http:// creativecommons.org/licenses/by/4.0/), which permits unrestricted use, distribution, and reproduction in any medium, provided you give appropriate credit to the original author(s) and the source, provide a link to the Creative Commons license, and indicate if changes were made.

\section{References}

Arzul, G., M. Seguel, I. Guzman, and E. Erard-LeDenn. 1999. Comparison of allelopathic properties in three toxic Alexandrium species. Journal of Experimental Marine Biology and Ecology 232: 285-295. doi:10.1016/S0022-0981(98)00120-8.

Bange, H.W. 2006. Nitrous oxide and methane in European coastal waters. Estuaries, Coast and Shelf Science 70: 361-374.

Bange, H.W., U.H. Bartell, S. Rapsomanikis, and M.O. Andreae. 1994. Methane in the Baltic and North Seas and a reassessment of the marine emissions of methane. Global Biogeochemical Cycles 8: 465-480.

Bates, T.S., K.C. Kelly, J.E. Johnson, and R.H. Gammon. 1996. A revaluation of the open ocean source of methane to the atmosphere. Journal of Geophysical Research 101: 6953-6961.

Borges, A.V., and G. Abril. 2011. Carbon dioxide and methane dynamics in estuaries. In Biogeochemistry, Treatise on Estuarine and Coastal Science, ed. E. Wolanski and D.S. McLusky, vol. 5, 119-161. Waltham: Academic Press.

Borges, A.V., G. Abril, F. Darchambeau, C.R. Teodoru, J. Deborde, L.O. Vidal, T. Lambert, and S. Bouillon. 2015a. Divergent biophysical controls of aquatic $\mathrm{CO}_{2}$ and $\mathrm{CH}_{4}$ in the World's two largest rivers. Scientific Reports 5: 15614. doi:10.1038/srep15614.

Borges, A.V., F. Darchambeau, C.R. Teodoru, T.R. Marwick, F. Tamooh, N. Geeraert, F.O. Omengo, F. Guérin, T. Lambert, C. Morana, E. Okuku, and S. Bouillon. 2015b. Globally significant greenhouse gas emissions from African inland waters. Nature Geoscience 8: 637642. doi:10.1038/NGEO2486.

Borges, A.V., W. Champenois, N. Gypens, B. Delille, and J. Harlay. 2016. Massive marine methane emissions from near-shore shallow coastal areas. Scientific Reports 6: 27908. doi:10.1038/srep27908.

Bousquet, P., S.C. Tyler, P. Peylin, G.R. Van Der Werf, C. Prigent, D.A. Hauglustaine, E.J. Dlugokencky, J.B. Miller, P. Ciais, J. White, L.P. Steele, M. Schmidt, M. Ramonet, F. Papa, J. Lathière, R.L. Langenfelds, C. Carouge, and E.G. Brunke. 2006. Contribution of anthropogenic and natural sources to atmospheric methane variability. Nature 443: 439-443.

Cáceres, M., A. Valle-Levinson, H. Sepúlveda, and K. Holderied. 2002. Transverse variability of flow and density in a Chilean fjord. Continental Shelf Research 22: 1683-1698.

Castillo, M.I., U. Cifuentes, O. Pizarro, L. Djurfeldt, and M. Cáceres. 2016. Seasonal hydrography and surface outflow in a fjord with a deep sill: the Reloncaví fjord, Chile. Ocean Science 12: 533-544.

Damm, E., E. Helmke, S. Thoms, U. Schauer, E. Nöthing, K. Bakker, and R.P. Kiene. 2010. Methane production in aerobic oligotrophic surface water in the central Artic Ocean. Biogeosciences 7: 1099-1108.

De Angelis, M.A., and C. Lee. 1994. Methane production during zooplankton grazing on marine phytoplankton. American Society of Limnology and Oceanography 39 (6): 1298-1308.

De Angelis, M.A., and M.D. Miller. 1987. Methane in surface waters of Oregon estuaries and rivers. American Society of Limnology and Oceanography 32 (3): 716-722. doi:10.4319/1o.1987.32.3.0716. 
Ding, W., Z. Cai, H. Tsuruta, and X. Li. 2002. Effect of standing water depth on methane emissions from freshwater marshes in northeast China. Atmospheric Environment 36: 5149-5157.

Ding, W., Z. Cai, and H. Tsuruta. 2005. Plant species effects on methane emissions from freshwater marshes. Atmospheric Environment 39: 3199-3207.

Filipová, L., R. Hédl, and N. Covacevich. 2010. Variability of soil types in wetland meadows in the south of the Chilean Patagonia. Chilean Journal of Agricultural Research 70 (2): 266-277.

Florez-Leiva, L., E. Damm, and L. Farías. 2013. Methane production induced by dimethylsulfide in surface water of an upwelling ecosystem. Progress in Oceanography 112: 38-48. doi:10.1016/j.pocean. 2013.03.005.

Garratt, J.R. 1977. Review of drag coefficients over oceans and continents. Monthly Weather Review 150: 915-929.

González, H.E., M.J. Calderón, L. Castro, A. Clement, L.A. Cuevas, G. Daneri, J.L. Iriarte, L. Lizarraga, R. Martinez, E. Menschel, N. Silva, C. Carrasco, C. Valenzuela, C.A. Vargas, and C. Molinet. 2010. Primary production and plankton dynamics in the Reloncaví fjord and the Interior Sea of Chiloé, Northern Patagonia, Chile. Marine Ecology Progress Series 402: 13-30.

Grasshoff, K., M. Ehrhardt, and K. Kremling. 1983. Methods of sea water analysis, 63-97. Weinheim: Verlag Chem.

Grossart, H.-P., K. Frindte, C. Dziallas, W. Eckert, and K.W. Tang. 2011. Microbial methane production in oxygenated water column of an oligotrophic lake. Proceedings of the National Academy of Sciences of the United States of America 108 (49): 19657-19661. doi:10. 1073/pnas.1110716108.

Hanson, R.S., and T.E. Hanson. 1996. Methanotrophic bacteria. Microbiology and Molecular Biology Reviews 60 (2): 439-471.

Holmes, M.E., F.J. Sansone, T.J. Rust, and N. Poop. 2000. Methane production, consumption, and air-sea exchange in the open ocean: an evaluation base on carbon isotopic rations. Global Biogeochemical Cycles 14: 1-10. doi:10.1029/1999GB001209.

Hope, D., S. Palmer, M. Billet, and J. Dawson. 2001. Variation in dissolved $\mathrm{CO}_{2}$ and $\mathrm{CH}_{4}$ in a first order stream and catchment: and investigation of soil-stream linkage. Hydrological Processes 18: 3255-3275.

IPCC. 2013. Climate change 2013: the physical science basis. In Contribution of working group I to the fifth assessment report of the intergovernmental panel on climate change, ed. T.F. Stocker, D. Qin, G.K. Plattner, M. Tignor, S.K. Allen, J. Boschung, A. Naules, Y. Xia, V. Bex, and P.M. Midgley. Cambridge: Cambridge University Press $1535 \mathrm{pp}$.

Iriarte, J.L., R.A. Quiñones, and R.R. González. 2005. Relationship between biomass and enzymatic activity of a bloom-forming dinoflagellate (Dinophyceae) in the southern Chile $\left(41^{\circ} \mathrm{S}\right)$ : A field approach. Journal of Plankton Research 27: 159-166.

Iriarte, J.L., H.E. González, and L. Nahuelhual. 2010. Patagonian fjord ecosystems in Southern Chile as a highly vulnerable region: problems and needs. Ambio: A Journal of the Human Environment 39 (7): 463-466.

Jones, J.B., and P.J. Mulholland. 1998. Methane input and evasion in a hardwood forest stream: effects of subsurface flow from shallow and deep pathways. American Society of Limnology and Oceanography 43: $1243-1250$

Joosten, H., and D. Clarke. 2002. Wise use of mires and peatlandssbackground and principles including a framework for decisionmaking. International Mire Conservation Group / International Peat Society, 304 pp.

Kara, A.B., P.A. Rochford, and H.E. Hurlburt. 2003. Mixed layer depth variability over the Global Ocean. Journal of Geophysical Research 108 (C3): 3079. doi:10.1029/2000JC00073.

Karl, D., L. Beversdorf, K.M. Björkman, M.J. Church, A. Martinez, and E.F. DeLong. 2008. Aerobic production of methane in the sea. Nature Geoscience 1: 473-478.
King, G.M. 1984. Metabolism of trimethylamine, choline, and glycine betaine by sulfate-reducing and methanogenic bacteria in marine sediments. Applied and Environmental Microbiology 48 (7): 19-725.

King, G.M., M.J. Klug, and D.R. Lovley. 1983. Metabolism of acetate, methanol, and methylated amines in intertidal sediments of Lowes Cove, Maine. Applied and Environmental Microbiology 45: 18481853.

Kirschke, S., P. Bousquet, P. Ciais, M. Saunois, J.G. Canadell, E.J. Dlugokencky, P. Bergamaschi, D. Bergmann, D.R. Blake, and L. Bruhwiler. 2013. Three decades of global methane sources and sinks. Nature Geoscience 6: 813-823.

Lai, D.Y.F. 2009. Methane dynamics in northern peatlands: a review. Pedosphere 19: 409-421.

Lange, C. 2012. International colloquium climate change in Magellan and Antarctic regions: evidence and challenges for the future session 3. Research highlights from the Chilean fjords: water column and sediments. Anales del Instituto de la Patagonia (Chile) 40 (1): 87-89.

León-Muñoz, J., R. Marcé, and J.L. Iriarte. 2013. Influence of hydrological regime of an Andean river on salinity, temperature and aspects of the structure and variability of the low oxygen in a Patagonia fjord, Chile. New Zealand Journal of Marine and Freshwater Research 47 (4): 515-528.

Letelier, J., L. Soto-Mardones, S. Salinas, P. Osuna, D. López, H.H. Sepúlveda, E. Pinilla, and C. Rodrigo. 2011. Variability of wind, waves and currents in the north Chilean Patagonic fiords. Revista de Biología Marina y Oceanografia 46 (3): 363-377.

Liss, P.S., and L. Merlivat. 1986. Air-sea gas exchange rates: introduction and synthesis. In The role of air-sea exchange in geochemical cycling, ed. P. Buat-Menard, 113-129. Boston: Reidel.

Martínez-Lagos, J.F., M. Alfaro Salazar, and T.H. Misselbrook. 2010. Inventory of ammonia emissions from livestock production in los Lagos and los Ríos regions, Chile. Chilean Journal Agricultural Research 70: 95-103.

Matthews, E. 1994. Assessment of methane sources and their uncertainties. Pure and Applied Chemistry 66: 154-162.

Middelburg, J.J., J. Nieuwenhuize, N. Iversen, N. Høgh, H. de Wilde, W. Helder, R. Seifert, and O. Christof. 2002. Methane distribution in tidal estuaries. Biogeochemistry 59: 95-119.

Montero, P., G. Daneri, H.E. González, J.L. Iriarte, F.J. Tapia, L. Lizárraga, N. Sanchez, and O. Pizarro. 2011. Seasonal variability of primary production in a fjord ecosystem of the Chilean Patagonia: Implications for the transfer of carbon within pelagic food webs. Continental Shelf Research 31 (3-4): 202-215.

Nightingale, P.D., G. Malin, C.S. Law, A.J. Watson, P.S. Liss, M.I. Liddicoat, J. Boutin, and R.C. Upstill-Goddard. 2000. In-situ evaluation of air-sea gas exchange parameterisations using novel conservative and volatile tracers. Global Biogeochemical Cycles 14: 373-387.

Oremland, R.S., L. Marsh, and S. Polcin. 1982. Methane production and simultaneous sulphate reduction in anoxic, salt marsh sediments. Nature 296: 143-145.

Ploug, H., M. Kühl, B. Bucholz, and B.B. Jorgensen. 1997. Anoxic aggregates-an ephemeral phenomenon in the pelagic environment. Aquatic Microbial Ecology 13: 285-294.

Reeburgh, W.S. 2007. Oceanic methane biogeochemistry. Chemical Reviews 107: 486-513.

Rubio-Álvarez, E., and J. McPhee. 2010. Patterns of spatial and temporal variability in streamflow records in south central Chile in the period 1952-2003. Water Resources Research 46: W05514. doi:10.1029/ 2009WR007982.

Sansone, F., M.E. Holmes, and B. Popp. 1999. Methane stable isotopic ratio and concentration as indicators of methane dynamics in estuaries. Global Biogeochemical Cycles 13 (2): 463-474.

Sieburth, J.M., and P.L. Donaghay. 1993. Planktonic methane production and oxidation within the algal maximum of the pycnocline: seasonal 
fine-scale observations in an anoxic estuarine basin. Marine Ecology Progress Series 100: 3-15.

Sievers, A.H., and N. Silva. 2008. Progress in the oceanographic knowledge of Chilean inner waters, from Puerto Montt to Cape Horn, 53 58. Valparaíso: Comité Oceanográfico Nacional - Pontificia Universidad Católica de Valparaíso.

Silva, N., and S. Neshyba. 1979. Masas de agua y circulación geostrófica frente a la costa de Chile austral. Instituto Antártico Chileno 25 (26): 5-32.

Silva, N., C.A. Vargas, and R. Prego. 2011. Land-ocean distribution of allochthonous organic matter in surface sediments of the Chiloé and Aysén interior seas (Chilean Northern Patagonia). Continental Shelf Research 31: 330-339.

Sowers, K.R., and J.G. Ferry. 1983. Isolation and characterization of a methylotrophic marine methanogen, Methanococcoides methylutens gen. nov., sp. nov. Applied and Environmental Microbiology 45 (2): 684-690.

Stanley, E.H., N.J. Casson, S.T. Christel, J.T. Crawford, L.C. Loken, and S.K. Oliver. 2016. The ecology of methane in streams and rivers: patterns, controls, and global significance. Ecological Monographs 86: $146-171$.

Subpesca. 2016. Informe ambiental de acuicultura 2014 http://www. subpesca.cl . Accesed July 2016.

Sun, J., L. Steindler, J.C. Thrash, K.H. Halsey, D.P. Smith, A.E. Carter, Z.C. Landry, and S.J. Giovannoni. 2011. One carbon metabolism in SAR11 pelagic marine bacteria. PloS One 6 (8): e23973. doi:10. 1371/journal.pone.0023973.

Tapia, F., and S. Giglio. 2010. Fjord carrying capacity assessment models applicable to ecosystems in Southern Chile. Valdivia, Chile, 1-22.

Tsuruta, H., and X. Li. 2003. Key factors affecting spatial variation of methane emissions from freshwater marshes. Chemosphere 51: $167-173$.

US Environmental Protection Agency (US EPA). 2010. Methane and nitrous oxide emissions from natural sources. Washington: U.S.
Environmental Protection Agency http://www.epa.gov/methane/ sources.html.

Valdés-Barrera, A., F. Repetto, A. Figueroa, and B. Saavedra. 2012. Knowledge and assessment of the patagonian's peatlands: opportunities and challenges proceedings of workshop: (24 \& 25 november, 2011, Punta Arenas). Anales Instituto Patagonia (Chile) 40 (2): 67-82.

Valentine, D.L. 2011. Emerging topics in marine methane biogeochemistry. Annual Review of Marine Science 3: 147-171.

Valle-Levinson, A., N. Sarkar, R. Sanay, D. Soto, and J. León. 2007. Spatial structure of hydrography and flow in a Chilean fjord, Estuario Reloncaví. Estuaries and Coasts 30 (1): 113-126.

Vandekerkhove, E., S. Bertrand, B. Reid, A. Bartels, and B. Charlier. 2016. Sources of dissolved silica to the fjords of northern Patagonia $\left(44-48^{\circ} \mathrm{S}\right)$ : the importance of volcanic ash soil distribution and weathering. Earth Surface Processes and Landform 41: 499-512. doi:10.1002/esp.3840.

Wanninkhof, R. 1992. Relationship between wind speed and gas exchange over the ocean. Journal of Geophysical Research 97: 7373-7382.

Weiss, R.F., and B.A. Price. 1980. Nitrous oxide solubility in water and seawater. Marine Chemistry 8: 347-359.

Wiesenburg, D.A., and N.L. GuinassoJr. 1979. Equilibrium solubilities of methane, carbon monoxide, and hydrogen in water and sea water. Journal of Chemical and Engineering Data 24 (4): 356-360.

Wolfe, R.S. 1971. Microbial formation of methane. Advance Microbial Physiology 6: 107-146.

Wuebbles, D.J., and K. Hayhoe. 2002. Atmospheric methane and global change. Earth-Science Reviews 57: 177-210.

Yevenes, M., E. Bello, S. Sanhueza, and L. Farías. 2016. Spatial distribution of nitrous oxide $\left(\mathrm{N}_{2} \mathrm{O}\right)$ in the Reloncaví Estuary, sound and adjacent sea $\left(41^{\circ}-43^{\circ} \mathrm{S}\right)$, Chilean Patagonia. Estuaries and Coasts. doi:10.1007/s12237-016-0184-z. 